This article has been accepted for publication in Globalizations (Dec 2020), published by Taylor \& Francis.

\title{
Development aid and transnational solidarity with African trade unions: walking the thin line
}

Zjos Vlaminck, Independent Researcher (corresponding author:

zjos.vlaminck@gmail.com)

Dr. Huib Huyse, HIVA, KU Leuven 
This article has been accepted for publication in Globalizations (Dec 2020), published by Taylor \& Francis.

\section{Abstract}

Trade unions have a long history of transnational solidarity in different forms and flavours. Since the 1990s unions in Northern countries have increasingly established structural mechanisms to support their Southern counterparts, including through Official Development Assistance (ODA). As a consequence trade unions on both sides of the equator have started to adopt aid discourses and practices. We examine how the increased encapsulation of trade union internationalism within the global development paradigm is reshaping the relations between African and Northern unions. Based on empirical data across several African countries we argue that trade union development cooperation (TUDC) is not a one way street. African unions are not passive recipients of aid but have used ODA to address structural weaknesses such as a declining membership and consequential loss of funds. Nevertheless, TUDC in practice often translates into programmes driven by resource- and capacity building-logics. Both findings bring a layered understanding of the transformative potential of TUDC.

Keywords: Trade Unions, Official Development Assistance, Transnational solidarity, Africa 
This article has been accepted for publication in Globalizations (Dec 2020), published by Taylor \& Francis.

\section{Introduction}

Since the 1970s processes of neoliberal globalization have weakened the labour movement and in response trade unions across the globe have adapted and reconceptualised their ways of organizing and claims-making (Kabeer 2018; Standing 2014). One important adaptation to the global restructurings of the world of work and increased mobility of capital has been the intensification of transnational trade union solidarity (Bieler et al. 2014). Although, labour transnationalism is not a new phenomenon, as Addenhoumne and Lévesque (2013) have thoroughly demonstrated, it has taken on different shapes in more recent years. One of the more recent, and often overlooked, expressions of modern day labour internationalism is Trade Union Development Cooperation (TUDC). TUDC consists of transnational labour solidarity which is funded by Official Development Assistance (ODA). Over the last decades Northern trade unions have been increasingly accessing ODA-funding lines to finance solidarity programmes in support of their partners in the South. Based on empirical data across several African countries we will examine the consequences of the incorporation of trade unions in the international development cooperation arena on the relations between Northern unions and their Southern counterparts and what this entails for a transformative labour agenda.

Whereas, over the last decade, there has been a rise in research on trade union internationalism (see e.g. Addenhoumne and Lévesque 2013; Breman and Van Der Linden 2014; Fairbrother et al. 2013; Munck 2002; Ghigliani 2005), and transnational solidarity (Ciccaglione \& Strickner 2014; Bieler et al. 2010; Bieler et al. 2014) studies on the relations between trade unions and the international donor community have been scarce. The majority of research on the subject is situated in the field of development studies and focusses on informal workers' organisations (e.g. Lindell 2009; Kabeer 2018). In our understanding the existing body of knowledge has four key shortcomings which we hope to address and overcome.

Firstly, trade union development cooperation is generally not seen as part of transnational solidarity initiatives conducted by the labour movement. Both in academic and 
This article has been accepted for publication in Globalizations (Dec 2020), published by Taylor \& Francis.

practitioners' circles they seem to exist in parallel with one and another. We however believe that TUDC should be framed as part and parcel of wider solidarity initiatives rather than perceiving it as a driver in its own right - and, as such, as part of the global labour movement's response to globalization. The ways in which trade unions have been able to tap into ODA-funding lines in support of workers in the South are, after all, an important tool to resist global neoliberal restructurings.

Secondly, the bulk of existing literature focusses on solidarity initiatives taken by Northern unions and misrecognizes the agency of southern trade unions in transnational solidarity processes. Following Bayart (2000), African actors are not passive subjects of processes of globalization and its related dependency vis a vis western states but have influence over how this dependency is shaped and perpetuated (Tull 2011: 8). So, instead of assuming that ODA-dependency has been imposed on the African labour movement, we argue that donorrelations are co-constructed and that African trade unions play an active role in maintaining these ODA-lines.

Thirdly, there is a dearth of information on the concrete ways through which ODA is channelled towards African trade unions and the specific implications of aid-modalities on the functioning of labour movements. Existing research tends to stay at macro- or mesolevel but fails to dig into the impact of donor-funding, which is traditionally designed for NGO-realities, on the governance system and organizing practices of African unions. ${ }^{1}$ Our analysis does dive into the nitty-gritty of ODA-funded programmes, unravelling the challenges they pose with regard to accountability and sustainability.

Fourth, and lastly, there is a tendency to adopt normative standpoints across all sides of the spectrum. Whilst Bernards (2017) for example, argues that the development programmes of the International Labour Organisation (ILO) are embedded in a "tripartite-fantasy" which has little resonance with African political and economic realities. Phelan (2011: 464) on the other hand, stipulates that "the directions in which [trade unions] are being pulled by their

\footnotetext{
${ }^{1}$ Some scholars have analysed the influence of international partners on the bargaining power of local (often informal) workers' organisations (see e.g. Lindell 2010; Andrea \& Beckman 2013). Others have pointed towards the competition over funding between trade unions and other civil society organisations in the global South (see e.g. McQuinn 2011 on Tanzanian trade unions).
} 
This article has been accepted for publication in Globalizations (Dec 2020), published by Taylor \& Francis.

latest benefactors are by and large positive ones". Rather than gauging whether donorrelations are good or bad we seek to understand what is driving them.

\section{Methodological and theoretical considerations}

Through a comparative analysis of 24 ODA-funded projects across 10 African countries, we will shed light on the interactions of Official Development Assistance (ODA) with African trade unions. Part of the data for this paper was collected in the context of evaluations of ODA-funded trade union development cooperation programmes implemented by five Belgian and three Dutch $\mathrm{SSOs}^{2}$ (Table 1). Qualitative research methods were used, including semi-structured interviews, participant observation and focus groups, executed by mixed teams of external international and domestic evaluators and researchers. On average, between 20 to 50 interviews and 3 to 10 focus groups were done for each of the 24 projects evaluated. For some evaluations quantitative data was also gathered through surveys taken from trade union members and workers in general. The empirical data was further contrasted against earlier research by the authors and finally embedded in existing academic debates through a literature review ${ }^{3}$. The confidentiality clauses in some of the evaluation contracts restrain the presentation of empirical data of specific nature. Therefore, the analysis below must be seen as overarching insights drawn from all 24 projects.

\section{Insert Table 1 here}

Theoretically, this article adopts Bayart's (2000) theory of extraversion as a lens to understand the nature of ODA-relations between African trade unions and their European partners. Digging deeper, on a micro-level, we build on Lévesque and Dufour-Poirier

\footnotetext{
${ }^{2}$ SSOs include both the international departments of Northern trade unions as well as NGOs working on decent work issues. The evaluations were executed through consortia of Belgian research institutes and consultancy groups, together with consultants based in the Global South.

${ }^{3}$ See, for example, Vlaminck et al. (2012) on funding practices of TUDC; Huyse (2010) on trade union perspectives on development effectiveness; Huyse (2015) on capacity development of trade unions; De Bruyn et al. (2017) on South-South trade union development cooperation.
} 
This article has been accepted for publication in Globalizations (Dec 2020), published by Taylor \& Francis.

(2005)'s analysis of the motives behind international labour solidarity to deepen our understanding of what is driving TUDC at present.

Extraversion, according to Bayart (2000), refers to the participation of African actors in processes of dependency. Whilst Bayart (2000) looked into the relations between African states and external actors, Pommerolle \& Simeant (2010) have demonstrated that dependency as "mode of action" can also be useful to understand the relations between African civil society organisations (CSOs) and international actors. By adopting this lens and seeing dependency as a dynamic process in which African actors actively participate, we move beyond a linear, one-directional analysis of trade union development cooperation. Therefore, African unions are not solely recipients of aid, instead, trade union development cooperation and related ODA-dependency is a result of processes, which are co-constructed and sustained by both African and European trade unions. In line with Pommerolle \& Simeant (2010) our findings suggest that despite the unequal power relations at the heart of TUDC, such as the fact that African unions have little leverage over how ODA is channelled to them, African unions have been able to instrumentalise these ODA-ties to take action. In this regard, our study also feeds into more recent studies looking into African agency in international politics which follow the same lines of thought, namely: Africa is not peripheral in international relations (see e.g. Chipaike \& Knowledge 2018: 5). More specifically, similar to conclusions Bayart has come to at the level of the state (Tull 2011:8), our findings suggest that African unions have partially sought after ODA to compensate for internal weaknesses. TUDC has, for example, allowed African unions to deal with the negative externalities of structural adjustment programs in the 1980s and 90s and more recent processes of globalization which have resulted in large scale informalization and a dramatic decline of membership.

However, whilst extraversion has been useful as a lens to understand the macro-level dynamics of TUDC, it provides little tools to analyse the extent to which ODA-relations contribute to a transformative labour agenda on an international level. To dig deeper into the rationale behind ODA-relations between African and European unions and their possible transformative capacities, we have used Lévesque and Dufour-Poirier (2005)'s analytical framework of labour internationalism. Lévesque and Dufour-Poirier (2005) have 
This article has been accepted for publication in Globalizations (Dec 2020), published by Taylor \& Francis.

identified different motives for trans- or international trade unionism which can be roughly grouped into three logics: the resource-driven logic, the capacity-building logic, and the transformational logic (Lévesque and Dufour-Poirier (2005: 537). According to the resource-driven logic unions engage in labour internationalism to access resources such as information, financial support as well as legitimacy. The capacity-building logic entails that unions engage with other unions on an international level in order to increase their capacity in terms of bargaining, organizing and other skills. The last set of motives for trade union internationalism has been labelled the transformational-logic. In this last logic unions seek out cross-border alliances in order to leverage change over processes of globalization which negatively impact workers worldwide. This is the only logic which is embedded in the interconnected interests of workers in different localities, aiming to bring about change on an international level. Whereas trade unions operating according to the first two logics build international alliances primarily in order to address national or local issues.

Adding to Lévesque and Dufour-Poirier (2005), our analysis is not only based on the discourse embedded in TUDC but also reveals how TUDC is implemented. By critically unpacking trade union development cooperation programmes differences between discourse and practice become clear. It is as this juncture that the opportunities and weaknesses of transformative TUDC can be found.

Our findings suggest that, despite a transformational discourse, TUDC at times remains stuck in resource- and capacity-building logics. As will be demonstrated below, TUDC programmes are very much focused on building the capacity of union leaders and key staff (and to a lesser extent members). On the other hand, from the perspective of African unions, gaining access to resources is primordial due to their financial insecurity. TUDC is also used to increase their bargaining power at a national level through global level advocacy in what Keck \& Sikkink (1998:12) have coined boomerang-approaches. So, similar to the extraversion theory international ties are used, in the first place, to achieve, national gains. Although it is believed that both capacity-building and availability of resources are foundations for creating and implementing a transformational agenda, we will stipulate below that the ways in which ODA-modalities play-out often leaves too little room and time to develop this driver. 
This article has been accepted for publication in Globalizations (Dec 2020), published by Taylor \& Francis.

\section{The emergence of trade unions within development cooperation}

Long before the term development cooperation emerged trade unions across the globe have been engaged in all kinds of solidarity activities (Addenhoumne and Lévesque 2013, 125; Fairbrother et al. 2013; Knowles and Eade 2005, 342). Trade unions can therefore be seen as forefathers of glocal movements, although initially trade union internationalism was limited to European borders. The 'politics of connectivity' - or seeking change in one particular spacial scale by taking action in another (Lindell 2009: 123) - has been a deliberate strategy of organised labour throughout its history (Fairbrother et al. 2013). Nonetheless the role of trade unions as change-makers in the Global South has long been underestimated by scholars and policy makers (Knowles \& Eade 2005). Even though the democratization wave which swept over Africa after the fall of the Berlin Wall resulted in a more diversified trade union landscape, the rising neoliberal paradigm led to the preference of NGOs as international do-gooders over their 'radical' counterparts (Edwards 2014; Knowles \& Eade 2005: 342; McQuinn 2011: 58).

Yet, slow but steady, from the 1990s onwards, African unions made their way into development circles. Spurred by a dwindling membership, partially caused by the Structural Adjustment Plans (SAPs), they started seeking donor funds (Beckman et al. 2010; Phelan 2011; Konings 2003). In parallel, since the 1980s in the USA, the Netherlands and the Scandinavian countries and more generally by the end of the 1990s, trade unions in the North gained recognition as development actors (Develtere 2012). This allowed European unions to tap into ODA-funding channels for their solidarity work in Africa instead of solely using internally generated funds. This shift was initiated during the World Summit for Social Development (Copenhagen, 1995), where international organisations such as the OECD and the World Bank (finally) concluded that working conditions should be seen as an integral part of economic and social development (Develtere 2012). The ILO's decent work agenda which has gained a lot of traction further consolidated this push (Jalles d'Orey 2017). More recently, with the drive for private sector-led development, the importance of sound industrial relations has been accentuated. Consequentially, trade unions are staged as vital actors to ensure that economic growth is more equally redistributed and to safeguard social peace which is favourable for attracting investors. In addition, the framing of the Sustainable Development Goals (SDGs), and specifically SDG 
This article has been accepted for publication in Globalizations (Dec 2020), published by Taylor \& Francis.

8 has given a fresh impetus by underscoring the importance of the decent work agenda and freedom of association as one of its pillars. These trends within the global development cooperation arena have led to an increase of ODA-funding for and partnerships between African and European unions.

In what follows we will dig into the nitty-gritty of trade union development cooperation to shed light on how these increased ODA-ties have shaped the relations between African trade unions and their European counterparts.

\section{Unpacking trade union development cooperation}

Although trade unions as well as many GUFs have internal trade union solidarity funds ODA has become an important source of funding for transnational solidarity (Develtere 2012). Significant data gaps make obtaining a detailed picture of the amounts of ODA channelled to trade unions development cooperation complicated but in an earlier study encompassing 18 Northern trade unions and SSOs we have however shown that ODAfunding for international trade union solidarity is on the rise (Vlaminck et al. 2012). Nevertheless trade unions still receive only a fraction of the ODA allocated to NGOsi.

ODA-funds can be channelled in a number of ways: through Northern trade unions in support of trade unions in the Global South or through international organisations such as the ILO, ITUC or the global union federations (GUFs). The programmes can be bilateral in nature or take on regional or thematic focusses. Whereas traditionally the beneficiaries of trade union development cooperation programmes were African unions or confederations, increasingly, informal workers' organisations are also being targeted. The gross of ODAfunding is used to support bilateral programmes between a union in the North and an African partner. The exact shape and form of TUDC differs, but projects often include capacity development components, such as strengthening the capacity to mobilise, engage in social dialogue, leadership training, and/ or training workers on labour rights. Joint advocacy campaigns at national or international level on decent work-related issues are another returning component in TUDC-partnerships. Thematically, gender, informal workers, occupational health and safety, and more recently, migration are recurrent topics in TUDC project outlines. 
This article has been accepted for publication in Globalizations (Dec 2020), published by Taylor \& Francis.

Financial viability vs. financial dependency

Overtime, ODA-funding has become a vital lifeline without which many African trade unions, federations and confederations most likely would not be able to operate effectively, specifically in a context of increased informalization. Out of ten African confederations included in our evaluation work between 2013 and 2015, nine had a high (>50\% of budget) or very high dependency (>70\% of budget) on international donor funding. Substantiating Bayart's (2000) extraversion theory and serving as an example of resource-driven labour internationalism (Lévesque and Dufour-Poirier 2005) this dependency has been mutually reinforced. On the one hand, through the increased accessibility of ODA-funding lines to Northern unions and SSOs and, on the other, through African unions' increased need for resources due to shrinking membership as a consequence of the weak performance of African economies and the growing influence of the neoliberal agenda. While the situation is less extreme for lower union structures, we found that unions who are dealing with precarious workers (domestic workers, agricultural workers, informal workers, etc.) tend to depend more on international donors than unions of formal workers. A confederation in West-Africa, for example, finances up to $90 \%$ of its work in the informal economy through ODA-funding and unionists stated that their work in the informal economy would not be possible without donor support ${ }^{\mathrm{ii}}$. Nonetheless, exceptions do exist, such as in Burundi for example where the FNTT - SI (La Fédération Nationale des Travailleurs du Transport, du Social et de l'Informel) contributed substantially more to COSYBU (Confédération des Syndicats du Burundi) in numbers and in terms of membership fees compared to the formal workers federations (data from 2016).

High dependency on ODA-funding - in particular for core activities - comes with a number of risks. Firstly, due to volatility of donor funding-lines and the changing nature of thematic and other conditionalities, African unions operate under significant financial insecurity. Donors and consequentially SSOs can quite abruptly decrease or stop funding or change conditionalities leaving their former partners ineligible to further financial support. Furthermore, the relatively short time-spans (between 2 to 4 years at the most) of ODA funding lines hinder long term financial planning. To deal with these insecurities African 
This article has been accepted for publication in Globalizations (Dec 2020), published by Taylor \& Francis.

unions have tried to diversify their donor-relations but having different donors comes with another set of difficulties, as we will see further on. Moreover, whereas African NGOs have increasingly sought alternative sources of income to decrease their dependency on international donors, the social business models they tend to adopt are problematic for many unions as they raise ideological dilemmas, such as: can unions be involved in profitmaking activities? Or how to align the capital interests with those of workers in such an endeavour?

Secondly, specifically in a context of organizing informal workers, the availability of donor-funding to a certain extent restrains unions from looking for effective ways of collecting membership fees. Because many informal workers' unions receive sufficient ODA to function effectively, there is little incentive to invest in the difficult tasks of collecting dues from their members. However, in cases were informal workers have been organized before the availability of international donor-funds, such as SEWA in India, collecting membership fees is a common practice. Whereas, many ODA-funded trade union development programmes include conditionalities regarding internally generated funds, in the case of informal workers it is often a-priori assumed that the collection of membership fees will not suffice to reach the required co-financing amount. This obliges union leaders of certain informal workers unions to divert time to other income-generating activities, such as providing catering services. For young unions these activities risk being at the cost of organizing and mobilizing practices. The assumption that informal workers are unable to pay dues, limits the potential of informal worker organisations and unions to invest in their financial independence whilst not losing sight from organizing workers. If donors keep on providing significant financial resources to create informal workers' unions and in a second phase expect them to become financially self-sustaining, there is a chance that both sides will end up disillusioned. Our research has shown that African union leaders are aware of these trade-offs but welcome donor-support for reaching out to informal workers because alternative sources of funding are seen to be less financially viable. Even many formal sector trade unions in Africa are struggling to collect substantial dues, due to a loss in membership and problems with non-payment (see e.g. Kalusopa et al. 2012). 
This article has been accepted for publication in Globalizations (Dec 2020), published by Taylor \& Francis.

\section{Upward accountability vs. organisational learning}

Our data suggests that increased ODA-relations can lead to trade unionists diverting time and energy away from their members in order to satisfy back-donor demands and interests. In contrast with Kaldor (2004: 24) who has proffered that trade unions suffer less from tensions between procedural (upward) and moral (downward) accountability, we have seen how procedural accountability has pushed aside processes of transformational partnerships and organisational learning. Our analysis hereby fits into the work of Crawford (2004) on North-South partnerships between NGOs and Bernards' (2017) analysis of ILO's development cooperation. It is not un-common for trade unionists to implement projects, write reports, or hold workshops for the sake of complying with donor requirements. This functionalist way of operating has left little room for interpretative processes, in which genuine learning between Northern and African unions, as well as amongst African trade unions members is achieved. African union members who actively participate in projects, reports or workshops under an ODA-umbrella might take home insights, but these are not systematically shared with the wider membership base.

In addition, we have found instances where knowledge sharing is focused on the ways of development cooperation or "being in". In some cases workshops are attended to increase one's social capital and in others as a means to obtain an extra income through the perdiems which are handed to participants or to have a free-meal. These are examples of extraversion, such as those identified by Pommerolle \& Simeant (2010), where the dependency on the international is used to increase one's own social status. On the other hand, we have also encountered African trade union members who have been eager in partaking in ODA-funded projects for the sake of increasing their knowledge, share that expertise with other union members, and manage to further strategic goals of their organisations. We have found that African unionist have generally adopted a pragmatic approach to meeting upward-accountability demands. From the perspective of African unionists ODA-relations are a key instrument to keep their unions financially afloat. Ensuring that access to ODA continues, even if projects have limited local ownership, can therefore over-shadow other goals of the partnership, confirming Lévesque and DufourPoirier (2005)'s resource-driven logic. The extent to which upward accountability influences the core-activities of the unions or confederations varies and depends on the 
This article has been accepted for publication in Globalizations (Dec 2020), published by Taylor \& Francis.

strength of the union or confederation. The creation of labour research departments in some countries through ODA, for example, would have been challenging without these external funds as it has given union leaders access to up to date knowledge on various labour issues and workplace conditions. LEDRIZ in Zimbabwe and the Labour Research and Policy Institute of Ghana's TUC are two prominent examples. The research conducted at both institutes has enabled trade unions to engage in evidence-based advocacy, increase bargaining power and develop long-term strategies.

Who sets the Agenda? The emergence of "development specialists"

The pressure to obtain more donor-funds forces African unions to pragmatically adapt their agendas with the risk of these agenda-changes being superficial and short-lived. Although one could argue that the agendas of donors embody important themes (see e.g. Phelan (2011:464) on social dialogue), it is important to critically reflect on the agenda-setting processes within the development cooperation context. Ordinary union members generally have little to say in the set-up, themes and implementation of the development cooperation programmes agreed on by their leadership. Typically, a handful of African union representatives and general secretaries are invited to partake in partnership consultationworkshops during the elaboration of new TUDC-programmes. Whilst their views are welcomed they represent a fraction of the union membership. Those present at partnership consultations have generally become "development specialists", who's core responsibility in the union is the implementation of ODA-programmes. We argue that these unionists due to their specific tasks and responsibilities - have limited incentives to do the difficult work of consulting and bargaining with the broader union membership-base. The creation of this internal "elite" has also resulted in conflicts of power between union leaders who are in and those who are out of these relatively closed ODA-circles. For these development specialists ODA sometimes serves a personal purpose besides that of the collective as they hope to increase their social status. So, both at the level of union members as discussed above as at that of higher ranking unionists, "being-in" the development circle might be used to increase ones social capital, substantiating notions of extraversion found by Pommerolle \& Simeant (2010) among African civil society members. 
This article has been accepted for publication in Globalizations (Dec 2020), published by Taylor \& Francis.

Nevertheless we have found that many of African trade unions we studied are struggling with the capricious nature of development cooperation agenda's, which can quickly alter based on a change of government or "new" discourses and hot topics within the international development arena. This has made it increasingly difficult for African trade unions to develop long term strategies and agendas. The Dutch government for example, puts substantial pressure on Dutch unions to develop strong lobby and advocacy components in their international programmes, especially related to supply chains which include Dutch companies. However, the actual needs, interests, and motivations of their African partners to put this strategy high on their agendas might vary. The same can be said for gender issues. Our findings indicate that the attention for gender in trade union development programmes is often steered in first instance by donors.

However, ODA has based on our findings not significantly influenced the broader political lines of trade union confederations. African trade union leaders have been able to maintain their independence when it comes to negotiations at the highest political levels.

Furthermore donor relations have in specific instances strengthened African unions' political leverage over national policies through the so-called boomerang effect (Keck \& Sikkink 1998: 12). The international backing African unions have obtained in their fight for social protection mechanisms serves as a good example. It is unlikely that social protection would be on the agenda of so many of African governments were it not for the pressure created by the ILO and other trade union development actors (Vlaminck et al. 2014).

Instrumentalising transnational solidarity

Perhaps the most intrusive of ODA-conditionalities has been the imposition of projectcycle management (PCM) tools by back-donors on Northern and, consequentially, their African counterparts. Although, the degree of imposition will differ from donor to donor, ODA-funding schemes tend to go hand in hand with results-based management (RBM) and monitoring and evaluation (M\&E) prescriptions (Vlaminck et al. 2012). There are signs that the increasingly strict ODA conditionalities of back-donors towards European unions have led to a growing instrumentalism in trade union development work. Our observations indicate that the time spend by union officials in fulfilling the project-cycle management (PCM) and monitoring and evaluation (M\&E) requirements is time that is taken away from grassroots' work and other core trade union activities. Moreover, the effectiveness of 
This article has been accepted for publication in Globalizations (Dec 2020), published by Taylor \& Francis.

TUDC is increasingly defined in terms of quantitative and measurable project outputs and outcomes, rather than in terms of their contribution to long term goals of building-up counter-hegemonic power and structural change. A comparative study of nine OECD-DAC donors (Verbrugge \& Huyse 2018) observes that especially the UK and the EU have gone far in setting-up conditionalities which aim at increasing effectiveness, efficiency, upward accountability and transparency, as well as introducing market-based mechanisms, such as competitive tendering and/or collaboration with the private sector, in their funding. Also Belgium and France have introduced new market-based mechanisms and conditionalities to force collaborations between CSOs. Germany, Sweden, and Denmark on the other hand stick to more traditional forms of framework funding, which leave more flexibility and put less emphasis on the RBM route (ibid).

All these conditionalities risk being in conflict with trade unions' internal organisational structures and force African unions into PCM and M\&E straightjackets which are difficult to align with the dynamic and often unpredictable arenas in which they operate.

Furthermore, as mentioned above, many African unions have multiple donors to decrease their financial insecurity, the flip-side of this multitude is that they find themselves juggling the agendas of various donors, each with their own project-cycle, M\&E requirements and thematic focusses. In addition, we have seen many examples of inefficient uses of ODAfunding as African trade unions are asked to organise the same type of workshops for different donors, as many donors have projects with comparable themes. These workshops might be attended by a similar group of people and virtually repeat themselves in content and set-up, decreasing the chance that they contribute meaningfully to learning and knowledge development.

Relatedly, unions run the risk of undermining their own governance systems by aligning multiple project-management cycles of different donors. We documented examples of African confederations which had to go through 3 to 4 different project-planning processes over a period of two to three years, most often not aligned with the timing of their respective congresses ${ }^{\mathrm{iii}}$. One African confederation in our sample reported that it had to write 240 monitoring reports for four SSOs over the course of two to three years. Another confederation judged it had to spend at least two to three months per year on report writing 
This article has been accepted for publication in Globalizations (Dec 2020), published by Taylor \& Francis.

for one SSO. In earlier research work done by one of the authors on the organisational capacity building instruments used by SSOs in their cooperation programmes 2015), it emerged that SSOs were using different tools, and that often Southern trade unions were confronted with different capacity building instruments and demands from different SSOs supporting them. In one case, an African federation was asked to do another organisational capacity analysis with an instrument designed by the SSO after it had gone through an extensive and in-depth internal action-research process to determine organisational priorities for the future.

This lack of consultation between donors unnecessarily burdens African unions with project-managerialism. Donors, however, point to the back-donors as the ones responsible for the increased functionalism within North-South trade union partnerships. Belgian unions, for example, reported how they were put under substantial pressure from the Belgian Ministry of Development Cooperation to set-up parallel 'participatory' workshops and events to identify the needs of the workers of their partner unions in Africa. The ministry could not be convinced that the regular processes of membership consultation of the African unions could provide the kind of participation they envisaged.

Aside from the multitude of planning frameworks, we observed an over-reliance on quantitative indicators such as the number of collective bargaining agreements, which say little about the depth of the changes at the workplace. Whilst African unions, pushed by resource-driven logics, generally comply with the PCM-conditionalities, there are signs that they are looking for ways to create counter pressure, for example at the regional level. One example is the regional development cooperation network on TUDC. Through this network African unions hope to speak with one voice in negotiations with back-donors on ODA modalities, based on a coherent shared programme (TUDCN 2012). The extent to which the network will be able to mobilize African unions around these themes and impact on donor practices still remains to be seen. A first step has already been made through African unions' effective lobby to incorporate South-South cooperation in the ODAprogrammes of Belgian and Dutch SSOs. One of the Belgian SSOs actually made the support of South-South cooperation their main cooperation strategy. On the other hand in recent years some donors started questioning the stringent RBM agenda and are gradually 
This article has been accepted for publication in Globalizations (Dec 2020), published by Taylor \& Francis.

adopting aid modalities which are more flexible, less heavy, and show more respect towards recipients' own project management processes. The Dutch Dialogue and Dissent funding framework and its successor, the Power of Voices, are a case in point.

\section{Engineering 'new' Partnerships}

Moving away from the nitty-gritty of the implementation of TUDC-programmes there are two discourses within the international development cooperation arena, which are influencing African trade unionism by pushing towards forging 'new' partnerships. The first one is the development effectiveness discourse - stipulated in the Paris Declaration and reconfirmed in the Busan and Accra Declaration, the United Nations Development Effectiveness Partnership and the Sustainable Development Goals (OECD-DAC 2008; Simonetti \& Huyse 2011). The premises here is that for development to be effective partnerships across civil society and with private and public sector actors are key (Gallin 2000). Within this framing labour movements are nudged towards certain types of unionism, in which they play more constructive roles towards other social partners, partly at the cost of more political and activist types of strategies; favouring business-unionism over other more revolutionary types of labour movements. However, we have also come across SSOs which do not follow this donor-discourse. Some unions which have a more activist or militant take on industrial relations in Europe for example tend to support more radical unions in Africa.

The second discourse pushing unions towards partnerships with other CSOs is Social Movement Unionism (SMU). SMU, prescribes Northern and African unions to build alliances across the wider civil society spectrum, by combining popular struggles with workers' struggles and including marginalised groups such as informal workers (Webster \& Lambert 1988 in Pillay 2013, 11; Spooner 2004). The risk of the SMU-discourse is its normative character and lack of critical examination of the desirability and practical implications of the broad-based partnerships it envisages. Although there are examples of grass-roots developments of SMU, donors-driven partnerships tend to neglect underlying ideological and structural differences. Streetnet serves as an insightful case in this regard. Streetnet is an international NGO which supports the organisation and mobilization of informal workers. In some of their projects they do so by advising informal workers' associations to align with local trade unions while simultaneously supporting trade unions 
This article has been accepted for publication in Globalizations (Dec 2020), published by Taylor \& Francis.

to open their ranks to informal workers. This approach is grounded in the premises that trade unions are the best partner for informal workers because they generally have better access to government structures through social dialogue institutions. What is frequently overlooked, are the existing governance structures of informal workers' associations and their embedded relations with government institutions. In Ghana, for instance, associations of informal market women, Streetnet's primary target group, negotiate market fees, garbage collection and health and safety issues through their market queens. Market queens are the secretary generals of market associations - to borrow trade union jargon - and have historically been well connected to Ghana's political apparatus (Clark 1994). Instead of supporting these existing structures Streetnet has created parallel systems of representation through the national trade union confederation, which are functioning suboptimal because trade union logics and practices are difficult to coincide with those believed and adopted by market queen associations.

On the other hand, the organisation of informal workers is not solely a donor-driven agenda and has roots in the history African unionism. As one trade union official put it: "before the imposition of colonial labour laws the dichotomy between formal and informal workers was of little importance to the African labour movement. In fact, many of the first African trade unions were comprised of informal workers, such as motorcycle taxi-drivers". So, it was by colonial default that African trade unions became representatives of formal workers, weakening the ties with workers in the informal economy (Cooper 1996; Jeffries 1978; Orr 1966). However, more recently, in response to their dwindling membership-base, African unions have reaffirmed their commitment towards all workers. But in order to meet these aspirations the trade union movement needed additional resources. ODA was the (im)perfect solution. It has allowed African unions to deliver services, such as reaching out to informal workers, that based on their own revenues would be impossible. In this way, ODA-funds contribute to bridging the 'representation gap'. Although, as Britwum (2010) stipulates, many trade union confederation are grappling with how to regularize the status of informal workers' unions, for instance in terms of voting rights. In Ghana for instance the Union for Informal Workers Associations, (UNIWA) remains an associate [member of the Trade Union Council (TUC)] and is therefore ineligible to hold executive positions within the TUC (Osei-Boateng 2019: 9). 
This article has been accepted for publication in Globalizations (Dec 2020), published by Taylor \& Francis.

Trade union views on the quality of the partnership

A final perspective is provided through the application of the eight principles ${ }^{4}$ of trade union development effectiveness (TUDEP 2011) on 20 of the 24 project in the sample. The TUDEP framework is the trade union movement's answer to the aid effectiveness agenda (OECD 2008). In a self-assessment ${ }^{5}$ tool based on the TUDEP framework the quality of the partnership between Northern-based trade unions and Africa unions, 16 out of 20 projects scored good or very good. However, when including externally-assessed aspects such as effectiveness and sustainability in the analysis, about half of the projects were considered by the evaluation teams to have the potential to move beyond capacity-building and resource-driven logics (Lévesque and Dufour-Poirier 2005).

\section{The Untapped Potential of TUDC}

We can rightfully assume that development cooperation between African unions and European donors will remain an important part of transnational trade union solidarity for quite some time to come. Probably, the adversial global political economy will be around for the unforeseeable future and African unions are unlikely to be able to significantly shore up their own revenues based on membership fees or alternative financing models. Within this context, African unions as well as their European partners must ask themselves what they want future trade union development cooperation to look like. In this sense it might be useful to go back to Lévesque \& Dufour-Poirier's (2005) classification of drivers of international trade union solidarity. Will future trade union development cooperation be driven primarily by a need for resources from the side of African unions? Will capacitybuilding be the cornerstone of the development cooperation between trade unions or shall a genuine transformational agenda define the transnational solidarity relations with African unions?

\footnotetext{
${ }^{4}$ Eight principles are democratic ownership, autonomy, partnership, transparency, accountability, coherence, inclusiveness and equality, and sustainability

${ }^{5} \mathrm{~A}$ workshop-based self-assessment with programme staff and the leadership of African trade unions using questionnaires and group discussions during the evaluation field work.
} 
This article has been accepted for publication in Globalizations (Dec 2020), published by Taylor \& Francis.

Our findings suggest that the first two scenarios are more prevalent. Although rhetorically the transformational agenda is present in many development programmes the implementation of most projects focus on capacity building of African partners. Moreover, in reality, it is often difficult to implement large-scale ODA-funded projects which focus on international or regional transformations. In the context of increased globalization, where many of the leverage points are beyond the national level, trade union development cooperation should however take on a more international focus if it is to be genuinely transformative.

The obstacles for doing so are twofold. On the one hand, the RBM discourse has indirectly led to a preference for projects with a single partner in a single country as it is easier to show results within a national context in comparison to more complex international or regional spheres. On the other, several African unions included in this study are not too keen on projects with goals and operations at the regional or international level, as they do not necessarily align with their members' interests and short-term needs. Although, some trade unions, especially in Belgium and the Netherlands, uphold programmes based on international advocacy, our findings indicate that a majority of ODA-budgets is spent on projects anchored within nation-states. That is, they aim at reaching national goals; improving labour conditions and industrial relations within a given partner country. Even within South-South cooperation, which has seen a significant increase, the focus seems to lie primarily on what trade unions in country $\mathrm{x}$ can learn from trade unions in country $\mathrm{y}$; not on how trade unions from countries $\mathrm{x}$ and $\mathrm{y}$ can join forces to address regional or global labour injustices. With their focus on international value-chains connected to the operations of Dutch companies, donor-funded programmes such as Dialogue and Dissent in the Netherlands, provide a new arena for trade unions to work at the international level. However, the jury is still out if the rather short-term modalities of this funding line is conducive for transformational change.

Lastly, the functionalism and managerialism brought by ODA to international trade union solidarity has in some instances further restrained critical thinking on what a global transformational agenda should entail and how it could be achieved. In this sense TUDC encompasses many possibilities yet to be explored. Whilst ODA has created linkages 
This article has been accepted for publication in Globalizations (Dec 2020), published by Taylor \& Francis.

between trade unions and workers across the world- the key to unlocking their potential might lie in mobilizing them in pursuit of alternative realities or a true transformational agenda. It is up to the global labour movement to decide which path they wish to take.

\section{Author details}

Zjos Vlaminck, Independent Researcher

Email address: zjos.vlaminck@gmail.com

Address: 
This article has been accepted for publication in Globalizations (Dec 2020), published by Taylor \& Francis.

Armando Moock 4204

Macul, Santiago

Chile

Mobile number: 00542616850942

Short Biography:

Zjos Vlaminck holds a master's degree in Political Science from the University of Ghent Belgium and Stellenbosch University in South Africa, with a major in African Studies (2010). She obtained a second master in Development Evaluation and Management from the Institute for Development Policy and Management in Antwerp (2011), where she narrowed her focus on Western Africa through her fieldwork and research in Ghana. After graduating she worked as a junior researcher at the Institute for Work and Society (HIVA), KU Leuven, Belgium (2011) and as a project manager, research assistant and junior researcher at the African Studies Centre in Leiden (2012-2014). She currently works as an independent researcher and primarily does consultancies for trade unions and NGOs, The common thread throughout her research has been unequal power relations and how local agents deal with adverse incorporation.

Dr. Huib Huyse, head of the sustainable development research group at HIVA-KU Leuven, Belgium

Email address: Huib.Huyse@kuleuven.be

Address:

HIVA Sustainable Development Research Group

Parkstraat 47 - box 5300

3000 Leuven

Belgium

room: 03.13

Telephone number: $+\underline{+3216320458 \text { or }+3216323128}$

Short Biography

Dr. Huib Huyse (1970) has a doctorate in international education from the University of Sussex (2011). He heads the research group on Sustainable Development at HIVA - KU Leuven. A substantial part of his research and evaluation work is policy- or practiceoriented and covers topics related to development cooperation and global development. Over the years, he has gradually moved his area of focus to non-traditional actors in development cooperation, including trade unions, informal worker organisations, business, and social economy organisations. He hosts a research chair on Decent Work and the SDGs. 
This article has been accepted for publication in Globalizations (Dec 2020), published by Taylor \& Francis.

\section{References}

Adanhounme, A. B., and C. Lévesque (2013) 'Creating Spaces for Labour Internationalism: National Industrial Unions in the Southern Hemisphere and Their Strategies', in 
This article has been accepted for publication in Globalizations (Dec 2020), published by Taylor \& Francis.

Fairbrother, P., C. Lévesque and M.-A. Hennebert (eds) Transnational Trade Unionims: Building Union Power, pp 121-140. Oxford: Routledge.

Andre, G. \& B. Beckman (2013) 'ASR Forum: Engaging With African Informal Economies', African Studies Review, 56, pp191-208.

Bayart, J.-F. (2000) 'Africa in the World : a History of Extraversion', African Affairs, 99(395), pp217-267.

Bieler, A., I. Lindberg \& W. Sauerborn (2010) 'After 30 Years of Deadlock: Labour's Possible Strategies in the New Global Order', Globalizations, 7 (1-2), pp247260, DOI: $10.1080 / 14747731003593653$

Bieler, A., J. Hilary \& I. Lindberg (2014) 'Trade Unions, 'Free Trade', and the Problem of Transnational Solidarity: An Introduction', Globalizations, 11 (1), pp1-

9, DOI: $10.1080 / 14747731.2014 .860319$

Beckman, B., S. Buhlunhu, S. and L. Sachikonye (2010) Trade Unions and Party Politics: Labour movements in Africa, Cape Town: HSRC Press.

Bernards, N. (2017) 'The International Labour Organization and African trade unions: tripartite fantasies and enduring struggles', Review of African Political Economy, 44(153), pp99-414. https://doi.org/10.1080/03056244.2017.1318359

Breman, J. and M. Van der Linden (2014), 'Informalizing the Economy: The Return of the Social Question at a Global Level', Development and Change 45 (5), pp920-940.

Britwum, A.O. (2010) 'Union Democracy and the Challenge of Globalisation to Organised labour in Ghana'. PhD dissertation, University of Maastricht, Maastricht.

Chhachhi, A. (2014), 'Introduction: The 'Labour Question' in Contemporary Capitalism', Development and Change 45 (5), pp895-919.

Ciccaglione, B. \& A. Strickner (2014) 'Global Crises: The Need to Go Beyond Transnational Solidarity in the Struggle Against the Expansion of Free Trade Agreements', Globalizations, 11 (1), pp143-153, DOI: 10.1080/14747731.2014.860805

Chipaike R. \& M.H. Knowledge (2018) 'The question of African agency in international relations', Cogent Social Sciences, 4 (1), pp 1-16

Clark, G. (1994) Onions are my Husband: Survival and Accumulation by West African Market Women, Chicago and London: University of Chicago Press.

Cooper, F. (1996) Decolonization and African Society: The Labor Question in French and British Africa, Cambridge: Cambridge University Press.

Crawford , P. (2004) 'Aiding Aid: a Monitoring \& Evaluation Framework to Enhance International Aid Effectiveness', PhD dissertation, Institute for Sustainable Future, Sydney.

Develtere, P. (2012) How do we help: The Freemarket in Development Aid, Leuven: Leuven University Press. 
This article has been accepted for publication in Globalizations (Dec 2020), published by Taylor \& Francis.

Eade, D. (2004) 'International NGOs and unions in the South: worlds apart or allies in the struggle?', Development in Practice 14(1-2), pp71-84.

Edwards, M. (2014) Civil Society, Stafford BC: Polity.

Fairbrother, $\underline{P .}, \underline{C}$. Lévesque and $\underline{M}$. Hennebert (eds) (2013) Transnational Trade Unionism Building Union Power, Oxford: Routledge.

Gallin, D. (2000) 'Trade Unions and NGOs: A Necessary Partnership for Social Development', Civil Society and Social Movements Programme Paper no1, Geneva: United Nations Research Institute for Social Development.

Ghigliani, P. (2005) 'International Trade Unionism in a Globalizing World: A Case Study of New Labour Internationalism', Economic and Industrial Democracy 26, pp359-382.

Gumbrell-McCormick, R. (2013) 'The International Labour Movement: Structures and Dynamics', in P. Fairbrother, C. Lévesque and M. Hennebert (eds) Transnational Trade Unionism Building Union Power, pp. 183-202, Oxford: Routledge.

Huyse, H. (2015) 'Trade Union Organisational Capacity tool (TUOC-tool). Trade Union Development Cooperation Network', Brussels: TUDCN. Accessed online on 16 Dec 2019: https://www.ituc-csi.org/IMG/pdf/tuoc guidelines.pdf

Jalles d'Orey, M. (2017) 'How do donors support the Decent Work Agenda? A Review of Five Donors', Brussels: TUDCN.

Jauch, H. (2010) 'Serving workers or serving the party? Trade unions and politics in Namibia', in Beckman, B., S. Buhlunhu, S. and L. Sachikonye (eds.) (2010): Trade Unions and Party Politics: Labour movements in Africa, Cape Town: HSRC Press.

Jeffries, R. (1978) Class, Power and Ideology in Ghana: the Railuiaymen of Sekondi, Cambridge: Cambridge University Press.

Kabeer, N. (2018) 'Women workers and the politics of claims-making: the local and the global', Development and Change, 49 (3), pp759-789. ISSN 0012-155X

Kaldor, M. (2003) 'Civil Society and Accountability', Journal of Human Development 4(1), pp5-27.

Keck,M.E. and K. Sikkink (1998) Activists beyond Borders: Advocacy Networks in International Politics, Ithaca, NY: Cornell University Press.

Konings, P. (2003) 'Organised labour and neo-liberal economic and political reforms in west and central Africa’, Journal of Contemporary African Studies, 21 (3), pp447-471.

Knowles, C. and D. Eade (2005) Labor Unions and Development: An Annotated List of Selected Resources.

http://www.developmentinpractice.org/sites/developmentinpractice.org/files/Labor\%20Uni ons\%20Resources.pdf (accessed on 27 August 2014) 
This article has been accepted for publication in Globalizations (Dec 2020), published by Taylor \& Francis.

Lévesque, C. and M. Dufour-Poirier (2005) ‘ International Union Alliances : Evidence from Mexico', Transfer 11(4), pp531-548.

Lindell, I. (2009) 'Glocal Movements: Place Struggles and Transnational Organising by Informal workers', Geografiska Annaler series B-Human Geography 91B (1), pp123-136.

Lindell, I. (ed) (2010) Africa's Informal Workers. Collective Agency, Alliances and Transnational Organising in Urban Africa, London: Zed Books.

Madounga, N. and G. Fonteneau (1998) Le mouvement syndical en Afrique noire.

Contributions pour une histoire, Brussels: Solidarité Mondiale.

McQuinn, M. (2011). Civil Society as a Conflictual Sphere in Post-liberalization Tanzania: The Roles of NGOs and Trade Unions. Phd dissertation, School of Oriental and African Studies, London.

Munck, R. (2002) Globalisation and Labour: The New 'Great Transformation, London: Zed Books.

OECD-DAC (2008) 'The Paris Declaration on Aid Effectiveness and the Accra Agenda for Action', Paris: OECD.

Orr, C. A. (1966) 'Trade Unionism in Colonial Africa', The Journal of Modern African Studies 4(01), pp65-81.

Osei-Boateng, C. (2019) Informal Workers and Social Dialogue in Ghana: The case of UNIWA and the Accra Municipality Assembly, Amsterdam: FNV Mondiaal

Phelan, C. (2011), 'Trade Unions, Democratic Waves, and Structural Adjustment: The Case of Francophone West Africa', Labor History 52 (4), pp461-481.

Pillay, D. (2013) 'Between Social Movement and Political Unionism: COSATU and Democratic Politics in South Africa', Rethinking Development and Inequality 2, pp10-27.

Pommerolle, M-E. \& J. Simeant (2010) 'L'internationalisation du militantisme en Afriqu', Alternatives Sud, 17, pp 229-234.

Simonetti, P. and H. Huyse (2011) Trade Union Principles and Guidelines on Development Effectiveness, Brussel: Trade Union Development Cooperation Network.

Spooner, D. (2004) 'Trade unions and NGOs: the need for cooperation', Development in Practice 14 (1-2), pp19-33.

Standing, G. (2014) 'Understanding the Precariat through Labour and Work', Development and Change, 45 (5), pp963-980.

TUDCN (2011) 'Trade Union Development Effectiveness Profile tool: TUDEP'. https://www.ituc-csi.org/tu-development-effectiveness-10464 (accessed on 31 May 2020) 
This article has been accepted for publication in Globalizations (Dec 2020), published by Taylor \& Francis.

TUDCN (2012) 'African Trade Unions Consultation: new perspectives for development cooperation in the continent - International Trade Union Confederation'. http://www.ituccsi.org/african-trade-unions-consultation on 10/11/2014 (accessed on 15 February 2016)

TUDCN (2014) 'Sustainable development through decent work: Activities report 20082012', Brussels: Trade Union Development Cooperation Network.

TUDCN (2015) Organisational Capacity Assessment 2015 seminar, Brussels March 2018, accessed online on 30 November 2019: https://www.ituc-csi.org/organisational-capacityassessment

TUDCN (2017) 'Social dialogue as a driver and governance instrument for sustainable development'. ILO-ITUC Issue Paper no 2, Geneva: ILO

Tull, D.M. (2011) 'Weak states and successful elites: extraversion strategies in Africa'. SWP Research Paper, Berlin: Stiftung Wissenschaft und Politik

UN General Assembly, Transforming our world: the 2030 Agenda for Sustainable Development, 21 October 2015, A/RES/70/1, available at:

http://www.refworld.org/docid/57b6e3e44.html [accessed 15 June 2018]

Verbrugge, B.; Huyse, H. (2018) 'Donor relationships with development CSOs at a crossroads? A comparative study of changing funding realities in 6 European countries', Leuven: HIVA-KU Leuven

Vlaminck, Z., R. Peels, and H. Huyse, (2012). 'Trade Union Support Mechanisms: An analysis of 18 donor countries', Leuven: HIVA-KU Leuven.

Vlaminck Z.,M. Dekker., A.H.M. Leliveld and U. Oberst (2014) 'Rome wasn't built in a day: the accessibility of social protection for informal workers: a mapping of 5 West African countries'. Amsterdam: CNV International. https://openaccess.leidenuniv.nl/bitstream/handle/1887/32122/ASC-075287668-361801.pdf?sequence $=1$ (accessed 10 September 2017) 
This article has been accepted for publication in Globalizations (Dec 2020), published by Taylor \& Francis.

i Exact figures of ODA going to trade union development cooperation are not known, but with the strong increase in ODA-funding for Civil Society Organisations (CSOs) over the last decade there are indications that ODA-funding to trade union work has witnessed a significant rise. A similar picture emerges from a 2012 study (Vlaminck et al. 2012) where the researchers found that in the period 2008-2011 10 out of 18 Northern-based solidarity support organisations were dependent on ODA for two-thirds or more of their total budget, another four were dependent for a quarter to half of their funding.

ii Interview with Anthony Baah TUC 2015

iii Planning activities involve for example the identification of new services for the membership, or were based on organisational capacity assessments to identify areas to strengthen the capacity of the unions (e.g. around project management, accountancy, lobby \& advocacy...). 